\title{
Leaders as Distinction Generators
}

\author{
Wiley W. Souba1, Matthew H. Souba ${ }^{2}$ \\ ${ }^{1}$ Department of Surgery, Geisel School of Medicine, Dartmouth College, Hanover, NH, USA \\ ${ }^{2}$ Department of Philosophy, Ohio State University, Columbus, OH, USA \\ Email: chip.souba@dartmouth.edu,souba.2@osu.edu
}

How to cite this paper: Souba, W. W., \& Souba, M. H. (2018). Leaders as Distinction Generators. Open Journal of Leadership, 7, 145-154.

https://doi.org/10.4236/oj1.2018.72008

Received: March 19, 2018

Accepted: June 2, 2018

Published: June 5, 2018

Copyright $\odot 2018$ by authors and Scientific Research Publishing Inc. This work is licensed under the Creative Commons Attribution International License (CC BY 4.0).

http://creativecommons.org/licenses/by/4.0/

\section{(c) (i) Open Access}

\begin{abstract}
In this article, we describe and illustrate, by way of examples, an important, though often underappreciated, role of leaders: a distinction generator. In the context of leadership, the idea of a distinction is to be understood as something someone says (spoken) or does that uncovers (discloses) for others a way of "seeing" an issue or a challenge that was previously imperceptible or unavailable. Distinctions, which are linguistic in nature, are crucial communication vehicles because they can evoke new ways of sense-making, thereby motivating others to change the way in which they talk, behave, and work together. In doing so, distinctions, by virtue of enabling us to see things in another light, become framing lenses (contexts) from and through which we live our lives differently. Distinctions, which are especially powerful during times of change and uncertainty, need not be grandiose inspirational elocutions; in fact, most are little " $\mathrm{d}$ " distinctions but this in no way lessens their potential for opening up and making available a new prospects for being and acting. In this sense, everyone, whether they have titular authority or not, can, simply by what they say, inspire others to put their best foot forward.
\end{abstract}

\section{Keywords}

Leadership Insights, Leadership Challenges, Linguistic Distinctions, Framing, Context, New Possibilities, Seeing in a Different Light

\section{Introduction}

Scholar James C. Humes, Professor of language and leadership at the University of Southern Colorado and a speechwriter for four American Presidents, wrote, "The art of communication is the language of leadership." (Humes, 2008). Humes' words are spot on. How do leaders clarify organizational goals and strategies? By means of communication. How do effective leaders align and mobilize people? Through clear communication. How do departments foster ac- 
countability? With straight communication.

Communication skills are even more critical during times of turbulent change, when insecurity and worry are common. During times of uncertainty and unpredictability, people have a tendency to hunker down in their comfort zone and play it safe. Under these circumstances, the leader's language becomes even more critical in maintaining alignment and progress. In addition to being clear, candid, and consistent, leaders must connect with others in a more humane way and inspire them to put their best foot forward. In this light and in these trying times, a powerfully important function of leaders, that of a distinction generator, can make a real difference. Curiously, this function has received little attention in the scholarly literature. The purpose of this article is to describe and illustrate, by way of examples, the leader's role as a distinction generator.

\section{What Is a Distinction?}

The word "distinction" as commonly understood, means, roughly, the quality or state of being distinguishable or different. This often involves seeing something in a different light. As used in this paper, in the context of leadership, the idea of a distinction is to be understood as something that is said (spoken) or done that uncovers (discloses) a way of "seeing" an issue or a challenge that was previously masked or unavailable. In so doing, new possibilities for action “open up." Distinctions, which are essentially linguistic in nature, relocate something-an idea, a way of seeing, a possibility-from an undifferentiated background into the open foreground (Magalhães, 2004; Souba, 2011; Zapolski \& Dimaggio, 2011). Said otherwise, sometimes, a mere few words or an action can open up a whole new world of possibilities for people, such that a course of action or an outcome that until now had not been contemplated, suddenly becomes available.

Take, for example, the well-known mantra of the New England Patriots professional football team, "Do Your Job” (Rodic, 2017). Popularized by Coach Bill Belichick, the message is unequivocally clear, concise, and consistent. Each player knows that he has an assignment on the football field and that he will be held accountable for that standard. There are no sacred cows; no one is exempt from criticism or discipline. Players are expected to go above and beyond and master all facets of their game.

But "Do Your Job" is more than just a communication slogan. Most powerfully, it is a linguistic distinction that has opened up a new way of "seeing", and ultimately a new way of being, such that it "uses" the athletes to perform at their best. It is a framing lens (Souba, 2016) or context from which the players have come to conduct themselves-on the field, in the weight room, during practice, and in the off season. It shapes how they eat, how much rest they get, and how must film they study. It is why no-name players have been able to succeed in New England and it is why the Patriots have been to the Conference Championship or to the Super Bowl twelve times since 2001.

Distinctions account for an often overlooked element of the power of language. The real power of language is not its ability to label, describe, and com- 
pare, but rather to create new futures. Distinctions are one means by which human beings articulate compelling futures that inspire others to change and create something new. Because distinctions are essentially linguistically constructed, they can be revised by means of language. The most successful distinctions are those that are "intended to evoke, and do evoke, a response of a certain kind in the man to whom it is addressed" (Johnstone, 1978). Thus, they are intended to create the space to consider new ways of being and acting. They are not simple rhetoric but rather "proceed by dint of a showing, a making manifest through the evocation of new life styles and new ways of seeing the world" (Schrag, 1986).

Distinctions act as framing lenses from, into, and through which we live our lives. They often become the gateway that allows us to step outside of what we know and what we're familiar with. Making a distinction can sometimes show up like a paradigm shift: a sudden change in perception, a sudden change in point of view, a sudden change in how one sees things. As clarified by Columbia professor Axel Honneth, distinctions function by disclosing the social world such that new interpretations and ways of seeing the world are possible:

A disclosing critique of society [a distinction] that attempts to change our value beliefs by evoking new ways of seeing cannot simply use a vocabulary of argumentative justification; rather, it can achieve its effects only if it employs linguistic resources that, by condensing or shifting meanings, show up facts hitherto unperceived in social reality (Honneth, 2007).

Said otherwise, the impact of a distinction is not due to the words themselves but rather that the words "disclose horizons of meaning that allow the entire web of our activities to appear in a different light" thereby "changing our value beliefs by evoking a new way of seeing the social world" (Honneth, 2007). This is why parables and metaphors can generate powerful distinctions. Harvard professor Steven Pinker says it this way: "Words themselves are not the ultimate point of communication. Words are a window into a world.... Unless the words can help the listener or the reader paint a mental picture, they won't be effective as a means of communication" (Pinker, 2018).

Distinctions are different than aha! moments, which are sudden insights that solve a problem, reinterpret a situation, or explain a joke (Kounios \& Beeman, 2009). In general, aha! moments do not function as contexts that alter the very reality in which people live. Distinctions, on the other hand, once made or "gotten," act as a framing lenses for making sense of the world around us differently such that new ways of being, speaking, and acting become available to us. In a very real sense, distinctions redefine the limits of what is possible for us. A new distinction doesn't alter what happened in a particular the situation (i.e., the facts); rather, the facts of the situation show up in a new light (frame).

No one, regardless of how poignant his or her oratory might be, can cause another person to "get" or make a distinction any more than anyone other than yourself can change you. And while leaders may say something that radically opens up new possibilities for one person, those same words may have no effect 
on another. For example, while John F. Kennedy's historic words, "Ask not what your country can do you, ask what you can do for your country," are understood intellectually by most people, their impact in terms of creating a distinction is quite variable. Not everyone contributes equally to the public good.

\section{Why Distinctions Are Important and How They Work}

Our interpretation of the world and our way of being and acting in the world, is given to us by the contexts and meanings embedded in the language we speak (Souba, 2010). Said otherwise, how a situation occurs for us lives in and arises in language. In Professor John Stewart's words, "everything in the world comes into existence in language, so that language does not 'represent' reality but discloses it" (Stewart, 1983). In order to lead more effectively, we need new ways of "seeing" our complex social issues. Unless and until these thorny dilemmas "show up" for us differently, our actions will not change. Distinctions communicate a vocabulary whose purpose is to elicit or provoke new possibilities for being, thinking, speaking, and acting.

How do leaders generate distinctions? They make use of a different way of "languaging" that often radically reshapes the way in which we understand leadership. As shown in Table 1, leadership distinctions can disclose possibilities for leading that radically contrast with conventional leadership dogma. In so doing, the way in which leaders exercise leadership shifts.

\section{Distinctions at Work}

How do leaders generate distinctions? They make use of a different way of "languaging" so as to unconceal the possibility of a new way of doing things, a new future. Sometimes the impact is striking while other times the breakthrough in "seeing" takes time. It took years for many people to appreciate the kind of world that could emerge out of Martin Luther King's distinction, "Injustice anywhere is a threat to justice everywhere". Most people still don't "get" the distinction. Granted, they genuinely feel regret when injustices occur, but they usually do not consider the possibility that such injustices could happen to them because of a broken system. King's distinction is about a system of justice that is biased and unfair. Thinking in the realm of his distinction "opens up" a space in which injustice can occur for people in a new way, thereby prompting change.

\section{1. "I Knew I Had to Do Something Different"}

Dick Fosbury, who won the gold medal in the high jump at the 1968 Olympics, captures the very essence of making a distinction. Fosbury invented a unique "back-first" technique, known since as the "Fosbury Flop", which is used by all high jumpers today (Brookes, 2016; Clear, 2018).

In the early 1960s, as a sophomore in high school, Fosbury had failed to clear the height required to compete in a high school track meet. At the time, high jumpers used what was known as the "straddle" technique, running up to and 
Table 1. Distinctions that call into question traditional leadership views.

\begin{tabular}{|c|c|}
\hline Conventional Leadership View & Leadership Distinction \\
\hline $\begin{array}{l}\text { Success as a leader is largely a function } \\
\text { of having the right strategic plan } \\
\text { and the necessary resources. }\end{array}$ & $\begin{array}{l}\text { "Greatness is not a function of circumstance. } \\
\text { Greatness, it turns out, is largely a matter of } \\
\text { conscious choice, and discipline" (Collins, 2001). }\end{array}$ \\
\hline $\begin{array}{l}\text { A leadership position grants one } \\
\text { authority and status. }\end{array}$ & $\begin{array}{l}\text { "Leadership is not rank, privileges, title or money. } \\
\text { It is responsibility" (Drucker, 1996). }\end{array}$ \\
\hline $\begin{array}{l}\text { Large-scale change efforts generally } \\
\text { fail because of a lack of implementation. }\end{array}$ & $\begin{array}{l}\text { "If there is no transformation inside each of us, } \\
\text { all the structural change in the world will have } \\
\text { no impact on our institutions" (Block, 1996). }\end{array}$ \\
\hline $\begin{array}{l}\text { The story of any leader's life resides } \\
\text { in his or her successes and failures. }\end{array}$ & $\begin{array}{l}\text { "The story of any one life, might be told in terms } \\
\text { of commitments" (Farley, 1986). }\end{array}$ \\
\hline $\begin{array}{l}\text { Great leaders are defined by their special } \\
\text { abilities. }\end{array}$ & $\begin{array}{l}\text { "It is not our abilities which make us who we are... } \\
\text { It's our choices" (Dumbledore, 2002). }\end{array}$ \\
\hline $\begin{array}{l}\text { I've become a leader through } \\
\text { my own hard work. }\end{array}$ & $\begin{array}{l}\text { "If I have seen further it is by standing on the } \\
\text { shoulders of giants" (Newton, 1675). }\end{array}$ \\
\hline My goal as a leader is to be very successful. & $\begin{array}{l}\text { "Try not to become a man of success but rather try } \\
\text { to become a man of value" (Einstein, 1955). }\end{array}$ \\
\hline Becoming a leader is about taking charge. & $\begin{array}{l}\text { "Becoming a leader is synonymous with becoming } \\
\text { yourself. It is that simple. It is that difficult" } \\
\text { (Bennis, 1994). }\end{array}$ \\
\hline $\begin{array}{l}\text { As a leader I want people to like me } \\
\text { and say nice things about me. }\end{array}$ & $\begin{array}{l}\text { "Being responsible sometimes means pissing people } \\
\text { off" (Powell, quoted in Harari, 2002). }\end{array}$ \\
\hline $\begin{array}{l}\text { My plan is so clear, understandable and } \\
\text { attractive, people will automatically change. }\end{array}$ & $\begin{array}{l}\text { "What people resist is not change per se, but loss. } \\
\text { When change involves real or potential loss, people } \\
\text { hold on to what they have and resist the change" } \\
\text { (Heifetz, Grashow, \& Linsky, 2009). }\end{array}$ \\
\hline $\begin{array}{l}\text { My central issue as a leader is to be } \\
\text { clear about our strategic vision. }\end{array}$ & $\begin{array}{l}\text { "The central issue is never strategy, structure, } \\
\text { culture, or systems. The core of the matter is always } \\
\text { about changing the behavior of people" (Kotter \& } \\
\text { Cohen, 2002). }\end{array}$ \\
\hline
\end{tabular}

jumping over the bar face-down. Given Fosbury's very average performance using the straddle technique (he never cleared six feet), he knew he had to do something radically different if he was going to compete at the highest level. At most schools at the time, the landing pit was made of sand or sawdust, which meant the jumper needed to land feet first in order to prevent injury. However, Fosbury's high school was one of the first to install a foam landing pit, which triggered a new way of seeing for him.

What if, instead of jumping the conventional way with his face toward the bar, Fosbury turned his body, arched his back, and went over the bar backwards while landing on his neck and shoulders? The physics behind his innovative approach turned out to be sound and the foam pit cushioned the landing, allowing him to land on his back. His technique was to sprint diagonally (rather than straight on) towards the bar, then turn and leap backwards over the bar, which gave him a lower center of gravity in flight than standard techniques (Barrow, 2012). Because the lower one's center of gravity the less energy required to suc- 
cessfully jump over the bar, Fosbury became more "airborne" and was able to clear greater heights.

Five years later, Fosbury broke all high jump records, winning gold at the 1968 Olympic games by clearing $7 \mathrm{ft} 4 \mathrm{in}$. More importantly, Fosbury's distinction took the high jump to a new level and changed the game itself. He did it not by working harder or becoming stronger, but by realizing that a convention need not be a rule. As a result of his distinction, something became possible that was not previously available.

\section{2. "I Am Prepared to Die"}

"I Am Prepared to Die" is the name given to Nelson Mandela's speech at his trial on April 20, 1964. He made his famous "speech from the dock" in which he said he was prepared to die for a democratic, non-racial South Africa. His speech held the court spellbound for more than three hours and ended with these words:

During my lifetime I have dedicated myself to this struggle of the African people. I have fought against white domination, and I have fought against black domination. I have cherished the ideal of a democratic and free society in which all persons live together in harmony and with equal opportunities. It is an ideal which I hope to live for and to achieve. But if needs be, it is an ideal for which I am prepared to die.

Mandela used language that illustrated "the struggle of the African people for the right to live." As pointed out by Keele University lecturer Awol Allo, "Mandela used words and phrases capable of re-inventing the political universe: touchstone phrases that resist what Apartheid affirms; reveal what it hides; and amplify what it silences" thereby highlighting a compelling paradox that at once "affirms disobedience and justifies it as a mark of the highest respect for Law" (Allo, 2014). By using his trial to appeal to the justice that resides in the deepest recesses of our humanity, Mandela personified that there are certain human values for which it is worth laying down one's life. In short, he created a distinction that opened up a new world of possibilities for justice and equality for all human beings.

Less than two months after giving his stunning speech, Mandela was convicted of sabotage and sentenced to life imprisonment on Robben Island. He served 27 years of the sentence before he was released and elected President of South Africa.

\section{3. "With Malice toward None, with Charity for All"}

In the aftermath of the Civil War, United Sates President Abraham Lincoln languaged an important distinction in his second inaugural address on March 4, 1865 (White, 2002). In spite of the rain and mud that flooded Pennsylvania Ave, thousands of Americans came to hear what the President had to say: 
With malice toward none, with charity for all, with firmness in the right as God gives us to see the right, let us strive on to finish the work we are in, to bind up the nation's wounds, to care for him who shall have borne the battle and for his widow and his orphan, to do all which may achieve and cherish a just and lasting peace among ourselves and with all nations.

Lincoln's words helped the American people "make sense" of what the nation stood for. He asked them to amend some of their long-standing beliefs and assumptions that were embedded in their life stories so they could take on the leadership challenge that faced them: creating a nation that took a resolute stand for the principles articulated in the Constitution.

Lincoln's distinction, "with malice towards none, with charity for all," created a context from which the American people, who had just experienced a horrific tragedy, could live their lives going forward. Instead of focusing on the Confederate attempt to secede from the union, Lincoln stressed the importance of moving ahead as a unified nation. His words challenged people to confront reality and revise their outdated ways of being and acting, thereby "opening up" the possibility of a new reality for the United States, one grounded in teamwork, unity, and peace.

\section{4. "Before My Teacher Came to Me, I Did Not Know that I Am"}

A stunning example of the role of a linguistic distinction in opening up a new world is found in Helen Keller's autobiographical account of her early childhood. Unable to see or hear from 18 months of age, she was both worldless and wordless, completely unable to experience life.

In 1887, at the age of seven, Helen Keller began working with a 20 -year-old named Anne Sullivan, herself visually impaired, who became Keller's instructor. It was the beginning of a relationship that lasted for half a century. Sullivan taught Keller by spelling words into her hand, beginning with "d-o-1-l" for the doll that she had brought Keller as a gift. For months Keller was frustrated and impatient because she was lacking the requisite linguistic interpretation and understanding that are part and parcel of seeing and hearing. Keller's breakthrough in communication came when she realized that the motions her teacher was making on the palm of her hand, while running cool water over her other hand, symbolized the idea of "water." Keller recounts the incident with her teacher that resulted in the distinction that forever changed her world:

As the cool stream gushed over one hand she spelled into the other the word water, first slowly, then rapidly. I stood still, my whole attention fixed upon the motions of her fingers. Suddenly I felt a misty consciousness as of something forgotten, a thrill of returning thought; and somehow the mystery of language was revealed to me. I knew then that "w-a-t-e-r" meant the wonderful cool something that was flowing over my hand. That living word awakened my soul, gave it light, hope, joy, set it free! (Keller, 2005). 
When Keller was awakened by her teacher to the meaning-function of language, she was awakened simultaneously to a self and a world: "Before my teacher came to me," she writes, "I did not know that I am. I lived in a world that was no-world. My inner life, then, was a blank without past, present, or future, without hope or anticipation, without wonder or joy or faith. When I learned the meaning of "I" and "me", and found that I was something, I began to think. Then consciousness first existed for me" (Keller, 2004).

Using language, Helen Keller opened up a new world for herself, one to which she previously had no access. With time, in spite of her physical impairments, she mastered language and, at the age of 24, graduated from Radcliffe, becoming the first deaf-blind person to earn a Bachelor of Arts degree. Over the course of her life she wrote twelve books and gave numerous speeches.

\section{Leveraging Distinctions as Tipping Points}

A contemporary understanding of communication must take into account the complex arrangement of verbal and nonverbal messages as well as intentional and unintentional messages, all of which influence the ways that leadership is exercised in a variety of settings (Ruben \& Gigliotti, 2017). What a leader says is important, but equally important, is how what is said, and what is unspoken but communicated.

Most distinctions are not as dramatic or impactful as those spoken by Nelson Mandela and Abraham Lincoln. And they certainly do not reach as many people. But when a single person gets a powerful distinction, the results can be remarkable, as Dick Fosbury demonstrated. Most distinctions are little "d" distinctions but that in no way lessens their impact once they open up and make available for us a new range of possibilities for being and acting. In this sense, everyone, whether they have an organizational title or not, can, simply by what they say, inspire others to put their best foot forward. And as more people become inspired by and aligned with the kind of world endorsed by Mandela and Lincoln, a tipping point can be reached when meaningful and unstoppable change ensues.

\section{References}

Allo, A. (2014). Nelson Mandela's “I Am Prepared To Die” Speech Fifty Years On. http://blogs.lse.ac.uk/africaatlse/2014/04/28/nelson-mandelas-i-am-prepared-to-die-sp eech-fifty-years-on/

Barrow, J. (2012). Mathletics: 100 Amazing Things You Didn't Know about the World of Sports. WW Norton: New York.

Bennis, W. (1994). On Becoming a Leader. New York: Addison-Wesley Publishing Co.

Block, P. (1996). Stewardship. Berrett-Koehler: San Francisco.

Brookes, I. (2016). Innovation Mindset: Lessons from Dick Fosbury. https://www.linkedin.com/pulse/innovation-mindset-lessons-from-dick-fosbury-ian-b rookes

Clear, J. (2018). Olympic Medalist Dick Fosbury and the Power of Being Unconventional. 
https://jamesclear.com/dick-fosbury

Collins, J. (2001). Good to Great. New York: Harper Collins.

Drucker, P. (1996). Forward. In F. Hesselbein, M. Goldsmith, \& Beckhard, R. (Eds.), The Leader of the Future: New Visions, Strategies and Practices for the Next Era (pp. 11-15). Jossey-Bass: San Francisco.

Dumbledore, A. (2002). Harry Potter and the Chamber of Secrets. Screenplay Written by JK Rowling.

Einstein, A. (1955). Death of a Genius: His Fourth Dimension, Time, Overtakes Einstein. In W. Miller (Ed.), Old Man's Advice to Youth: "Never Lose a Holy Curiosity." (pp. 62-64). New York: Time, Inc.

Farley, M. (1986). Personal Commitments. New York: HarperCollins.

Harari, O. (2002). 18 Leadership Principles from Colin Powell. New York: McGraw-Hill.

Heifetz, R., Grashow, A., \& Linsky, M. (2009). The Practice of Adaptive Leadership: Tools and Tactics for Changing Your Organization and the World. Boston: Harvard Business Press.

Honneth, A. (2007). Disrespect: The Normative Foundations of Critical Theory. Malden, MA: Polity Press.

Humes, J. (2008). The Art of Communication Is the Language of Leadership. http://www.freshbusinessthinking.com/the-art-of-communication-is-the-language-of-1 eadership/

Johnstone, H. (1978). Truth, Communication, and Rhetoric in Philosophy. In Validity, Rhetoric, and Philosophical Argument (pp. 67-78). University Park, PA: The Dialogue Press of Man and World.

Keller, H. (2005). The Story of My Life. New York, NY: Simon and Schuster.

Keller, H. (2004). The World I Live in. New York, NY: NYRB Classics.

Kotter, J., \& Cohen, D. (2002). The Heart of Change: Real-Life Stories of How People Change Their Organizations. Cambridge, MA: Harvard Business School Press.

Kounios, J., \& Beeman, M. (2009). The Aha! Moment: The Cognitive Neuroscience of Insight. Current Directions in Psychological Science, 18, 210-216.

https://doi.org/10.1111/j.1467-8721.2009.01638.x

Magalhães, R. (2004). Organizational Knowledge and Technology: An Action-Oriented Perspective on Organization and Information Systems. Northampton, MA: Edward Elgar. https://doi.org/10.4337/9781845420703

Newton, I. (1675) Letter to Scientist Robert Hooke. http://www.bbc.co.uk/worldservice/learningenglish/movingwords/shortlist/newton.sht $\underline{\mathrm{ml}}$

Pinker, S. (2018). Quoted in: Goudreau J. Harvard Psychologist Steven Pinker: The No. 1 Communication Mistake That Even Smart People Make.

http://blurbstory.com/post/cnbc.com/2018/02/20/harvard-psychologist-steven-pinkershares-no-1-communication-mistake.html? _ source=sharebar\%7Ctwitter\&par=shareb ar

Rodic, D. (2017). 5 Lessons Bill Belichick's New England Patriots Can Teach You about Leadership.

https://www.cnbc.com/2017/02/01/5-lessons-bill-belichick-and-the-patriots-can-teachabout-leadership.html

Ruben, B., \& Gigliotti, R. (2017). Communication: Sine Qua Non of Organizational Leadership Theory and Practice. International Journal of Business Communication, 54, 
12-30. https://doi.org/10.1177/2329488416675447

Schrag, C. (1986). Communicative Praxis and the Space of Subjectivity. Bloomington: Indiana University Press.

Souba, W. (2010). The Language of Leadership. Academic Medicine, 85, 1609-1618. https://doi.org/10.1097/ACM.0b013e3181ee0045

Souba, W. (2011). A New Model of Leadership Performance in Health Care. Academic Medicine, 86, 1241-1252. https://doi.org/10.1097/ACM.0b013e31822c0385

Souba, W. (2016). Resilience: Back to the Future. JAMA Surgery, 151, 896-897. https://doi.org/10.1001/jamasurg.2016.1056

Stewart, J. (1983). Interpretive Listening: An Alternative to Empathy. Communication Education, 32, 379-391. https://doi.org/10.1080/03634528309378559

White, R. (2002). Lincoln's Greatest Speech: The Second Inaugural. New York, NY: Simon \& Schuster.

Zapolski, N., \& DiMaggio, J. (2011). Conversations That Matter: Insights \& Distinctions-Landmark Essays (Vol. 1). San Francisco, CA: Landmark Worldwide. 